\title{
Relation between left ventricular gradient and relative stroke volume ejected in early and late systole in hypertrophic cardiomyopathy Assessment with radionuclide cineangiography
}

\author{
DECLAN D SUGRUE, „ WILLIAM J MCKENNA, SHAUGHAN DICKIE, \\ MELVYN J MYERS, J PETER LAVENDER, CELIA M OAKLEY, JOHN F GOODWIN \\ From the Departments of Medicine and Radiology, Royal Postgraduate Medical School, London
}

SUMMARY Hypertrophic cardiomyopathy is characterised by hyperkinetic left ventricular function, but the effect of an outflow tract gradient on the haemodynamics of ejection remains controversial. To determine the functional importance of left ventricular gradients in hypertrophic cardiomyopathy technetium-99m gated equilibrium radionuclide angiography was performed in 18 normal subjects and 57 patients, 26 with and 31 without left ventricular gradients. Time activity curves were generated from list mode data, and the proportion of stroke volume ejected during various phases of systole was computed. The proportion of stroke volume ejected during the initial third, the initial $50 \%$, and the initial $80 \%$ of systole was greater in patients with hypertrophic cardiomyopathy than in normal subjects but was identical in patients with and without left ventricular gradients. The duration of systole was similar in the three groups. These findings favour the interpretation that a left ventricular gradient does not represent true obstruction and are consistent with previous observations that clinical features and prognostic indicators do not relate to gradients in this disease.

The haemodynamics of left ventricular ejection in hypertrophic cardiomyopathy have been extensively investigated. ${ }^{1-7}$ Left ventricular outflow gradients have been noted and considered to be the primary haemodynamic abnormality in this disease. ${ }^{89}$ The clinical relevance of such gradients has subsequently been questioned, ${ }^{10-13}$ particularly because they do not relate to symptoms, ${ }^{914}$ arrhythmia, ${ }^{15} 16$ or sudden death. ${ }^{16-21}$ Though the characteristics of left ventricular ejection have been documented in patients with gradients, much less information is available for those without gradients. We therefore measured the proportion of left ventricular stroke volume ejected during early and late systole in patients with hyper-

\footnotetext{
Requests for reprints to Dr W J McKenna, Division of Cardiovascular Disease, Royal Postgraduate Medical School, Du Cane Road, London W12 OHS.
}

*Present address: Division of Cardiovascular Disease, Mayo Clinic, Minnesota, USA.

Accepted for publication 3 August 1984 trophic cardiomyopathy with and without a left ventricular gradient, using high temporal resolution time activity curves from gated radionuclide angiography.

\section{Patients and methods}

Fifty seven ( 31 men and 26 women) patients with hypertrophic cardiomyopathy were studied. They were aged 13 to 70 (mean (SD) 39(12)) years. The study population consisted of consecutive patients who showed sinus rhythm without left bundle branch block or significant mitral regurgitation. None had undergone previous surgery. The diagnosis of hypertropic cardiomyopathy was based on echocardiographic $^{22}$ or clinical ${ }^{8}$ and angiographic evidence of unexplained left ventricular hypertrophy. ${ }^{23}$

Cardiac catheterisation had been performed within three years before the study. The peak to peak gradient from left ventricle to aorta was obtained from simultaneous pressure recordings with a 7F Millar micromanometer tip catheter and sheath or two 
National Institutes of Health catheters $(7 F$ or $8 F$ ). The tip of the left ventricular catheter was positioned to prevent entrapment as a cause of spurious gradients. Left ventricular end diastolic volumes were calculated from contrast angiograms as previously described. ${ }^{24}$ Eight (14\%) patients had a gradient at rest of 30-65 (mean (SD) 42 (9)) $\mathrm{mm} \mathrm{Hg}$ (group 1). A gradient of $30-240(106(28)) \mathrm{mm} \mathrm{Hg}$ was present in 18 patients (32\%) (group 2) after provocation with amyl nitrate inhalation ${ }^{6}$ or the Valsalva manoeuvre ${ }^{7}$; none of these patients had a gradient of more than 30 $\mathrm{mm} \mathrm{Hg}$ at rest. Thirty one (54\%) patients did not have a gradient at rest or after provocation (group 3). The left ventricular end diastolic pressure was 5-34 (20 (5)) $\mathrm{mm} \mathrm{Hg}$ and was similar in all three groups. Coronary arteriography was performed in 12 patients aged 40 years or more; none had significant stenoses of epicardial coronary arteries. Table 1 shows the clinical and echocardiographic features of the patients. The echocardiographic criteria for determining the predominant pattern of left ventricular hypertrophy-such as asymmetrical septal, distal ventricular, or symmetrical hypertrophy-have been described previously. ${ }^{22}$ All patients underwent ambulatory electrocardiographic monitoring over 48 hours while they were not receiving treatment with drugs.

\section{GATED RADIONUCLIDE CINEANGIOGRAPHY}

$R$ wave gated equilibrium radionuclide cineangiography was performed at rest after the in vivo labelling of red blood cells with $555 \mathrm{MBq}(15 \mathrm{mCi})$ of technetium-99m. ${ }^{25}$ Cardioactive drugs were stopped at least 72 hours before this. Studies were recorded, while patients were in the supine position, with a gammacamera with a large field of view (General Electric $400 \mathrm{~T}$ ) and medium sensitivity parallel hole col- limator oriented in a $45^{\circ}$ left anterior oblique projection with caudal tilt to delineate maximally the ventricular septum. Data were acquired in list mode from 600 to 900 consecutive cardiac cycles and were stored on a computer (A2 multiterminal, Medical Data Systems) for subsequent analysis. An RR interval histogram was generated, and complexes falling outside an operator selected range (plus or minus $20 \%$ from the mean RR interval) were rejected. A background corrected left ventricular time activity curve was then constructed from the remaining complexes at a frame rate of $15 \mathrm{~ms} /$ frame. ${ }^{26}$ The change in left ventricular counts during the cardiac cycle approximated changes in volume ${ }^{27}$; however, knowledge of absolute left ventricular volume was not assumed. Each background corrected curve was smoothed using a five point least squares smoothing algorithm..$^{28}$ Left ventricular ejection fraction was calculated using a standard count based method. ${ }^{28}$ Peak ejection rate was computed in left ventricular counts from the systolic portion of the curve using a smoothing derivative formula. ${ }^{28}$ Rates were normalised to end diastolic counts as previously described for the right ventricle and expressed as the change from end diastolic volume per s (Fig. 1). The systolic ejection period was calculated manually as the time (ms) from the maximum to the minimum of the systolic portion of the volume curve (Fig. 1). Time (ms) to peak ejection rate was calculated as the interval from the maximum of the activity time curve to the point of peak ejection. Blood pressure and heart rate were recorded with the patient in the supine position at the time of radionuclide study.

Calculation of the relative ejected volume during early and late systole was based on a previously described angiographic technique. ${ }^{29}$ The systolic ejection period was divided into three equal periods $(\mathrm{CO}-\mathrm{C} 1, \mathrm{C} 1-\mathrm{C} 2$, and $\mathrm{C} 2-\mathrm{C} 3)$ and the proportion of

Table 1 Clinical and echocardiographic features in 57 patients with hypertrophic cardiomyopathy. Values are numbers (\%) of patients except where indicated

\begin{tabular}{|c|c|c|}
\hline & $\begin{array}{l}\text { Patients with a gradient } \\
(n=26)\end{array}$ & $\begin{array}{l}\text { Patients without a gradient } \\
(n=31)\end{array}$ \\
\hline $\begin{array}{l}\text { Mean (SD) age (yr) } \\
\text { Mean (SD) duration of symptoms (yr) } \\
\text { Family history of hypertrophic cardiomyopathy }\end{array}$ & $\begin{array}{l}41(12) \\
11.8(7)\end{array}$ & $\begin{array}{l}43(13) \\
7.4(8)\end{array}$ \\
\hline $\begin{array}{l}\text { and sudden death } \\
\text { Dyspnoea: }\end{array}$ & $10(39)$ & $7(23)$ \\
\hline $\begin{array}{l}\text { Mild to moderate } \\
\text { Severe }\end{array}$ & $\begin{array}{c}25(96) \\
1(4)\end{array}$ & $31(100)$ \\
\hline $\begin{array}{l}\text { Chest pain } \\
\text { Syncope } \\
\text { Ventricular tachycardia } \\
\text { Asymmetrical septal hypertrophy } \\
\text { Symmetrical hypertrophy } \\
\text { Distal hypertrophy } \\
\text { Mean (SD) thickest myocardial segment (mm) }\end{array}$ & $\begin{array}{l}18(69) \\
14(54) \\
8(30) \\
9(39) \dagger \\
12(52) \dagger \\
2(9) \dagger \\
23(6)\end{array}$ & $\begin{array}{l}18(58) \\
19(61) \\
7(23) \\
20(71) \dagger \\
7(25) \dagger \\
1(4) \dagger \\
22(4)\end{array}$ \\
\hline
\end{tabular}

*Ventricular tachycardia during ambulatory electrocardiographic monitoring defined as three or more consecutive ventricular extrasystoles with mean rate greater than 120 beats/minute.

†Adequate electrocardiographic recordings obtained in 23 patients with and 28 patients without left ventricular gradients. 


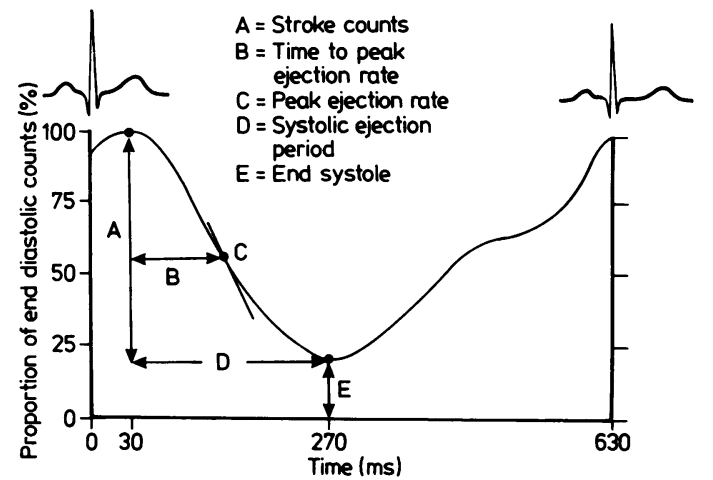

Fig. 1 Schematic representation of a left ventricular activity time curve. End systole was identified as the minimum of the curve. Systolic ejection period was defined as the interval from the maximum to the minimum of the curve. Peak ejection rate was computed using a smoothing derivative formula. Time to peak ejection rate was defined as the interval from the curve maximum to peak ejection rate.

stroke volume counts ejected during each third of systole was expressed as a percentage of total left ventricular stroke volume (Fig. 2). The left ventricular counts at points $\mathrm{C} 0$ and $\mathrm{C} 3$ were always known. Points $\mathrm{C} 1$ and $\mathrm{C} 2$ did not, however, always coincide exactly with a known value; under these circumstances the nearest known value was chosen (Fig. 2). Using a method identical to that described above, the

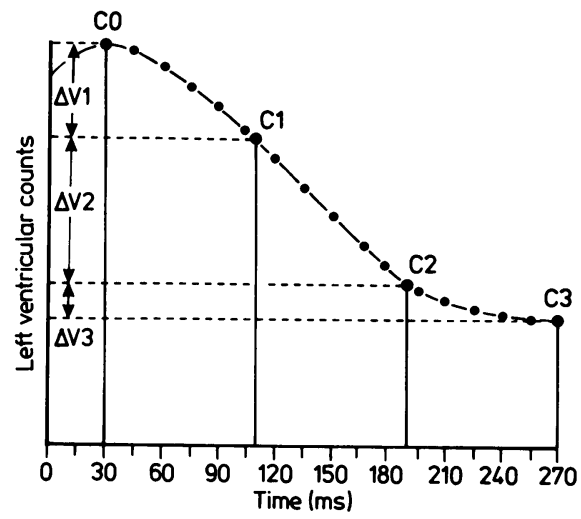

Fig. 2 Schematic representation of systolic portion of a high temporal resolution activity time curve (frame rate $15 \mathrm{~ms} /$ frame). $C 0$, counts at maximum of curve; $C 3$ counts at minimum of curve; $\mathrm{CO}-\mathrm{Cl}$, first third; $\mathrm{Cl}-\mathrm{C2}$, middle third; $\mathrm{C2}-\mathrm{C3}$, final third. The relative change in volume $(\Delta V)$ was expressed as a percentage of stroke volume during each third of the systolic ejection period and was calculated as: $\Delta V I$ (first

third) $=C 0-C 1 / C 0-C 3 \times 100 ; \Delta V 2$ (second

third $)=C 1-C 2 / C 0-C 3 \times 100 ; \Delta V 3($ final

third $)=C 2-C 3 / C 0-C 3 \times 100$. relative volumes ejected during the first half and first $80 \%$ of the period of systolic ejection were also calculated. Similar measurements were made for comparison in 18 normal volunteers (aged 17-36 (mean 24) years).

\section{REPRODUCIBILITY OF RADIONUCLIDE MEASUREMENTS}

We had previously assessed the reproducibility of measurements of systolic function obtained from two separate radionuclide studies performed one week to one month apart (unpublished data). In brief, the reproducibility of these measurements, expressed as the mean (SD) of the absolute difference between studies, was: ejection fraction 0.49 (4)\% (range 0-8); peak ejection rate $0.26(0.5)$ end diastolic volume/s (0.03-2.23); time to peak ejection rate 4 (25) $\mathrm{ms}$ (0-81); and time to end systole 10 (34) ms (0-94). Two independent observers calculated the proportion of stroke volume ejected during early and late systole to determine the interobserver variability of these measurements.

\section{STATISTICAL METHODS}

Data on the different groups were compared with an unpaired $t$ test. Normal ranges for radionuclide indices of ejection were defined by $95 \%$ confidence intervals. Data were expressed as mean plus or minus one standard deviation.

\section{Results}

Left ventricular ejection fraction in the 57 patients with hypertrophic cardiomyopathy ranged from 47 to 99 (74 (12))\% and was above the upper limit of normal in $24(42 \%)$ (Table 2; Fig. 3). Normalised peak left ventricular ejection rate ranged from 2.21 to 6.80 (3.82 (1.07)) end diastolic volume/s in patients and was above the upper limit of normal in 19 (33\%) (Table 2; Fig. 3). Mean values for left ventricular ejection fraction and peak left ventricular ejection rate were significantly higher for all patients compared with the normal subjects (ejection fraction $74(12) \% v$ $63(6) \%(p<0.001)$; peak ejection rate $3.82(1.13) v$ $3.14(0.3)$ end diastolic volume/s $(p<0.001))$. The time to peak ejection rate was shorter (114 (31) $v 136$ (18) $\mathrm{ms}(\mathrm{p}<0.01))$ in patients than in the normal subjects (Table 2); the duration of the systolic ejection period, RR intervals, and systolic and diastolic blood pressure were similar in patients and normal subjects. There were no significant differences in heart rate, blood pressure, or any measurement of left ventricular ejection in patients with resting or provocable left ventricular gradients or in those without such gradients (Table 2; Fig. 3). End diastolic volumes were identical in each group (group 1, 134 (26) (range 80- 
Table 2 Radionuclide measurements of left ventricular ejection in normal subjects and in patients with hypertrophic cardiomyopathy with a gradient at rest (group 1), a gradient on provocation (group 2), or no gradient (group 3)

\begin{tabular}{|c|c|c|c|c|c|c|c|c|}
\hline & \multirow{2}{*}{\multicolumn{2}{|c|}{$\begin{array}{l}\text { Normal subjects } \\
(n=18)\end{array}$}} & \multicolumn{6}{|c|}{ Patients with hypertrophic cardiomyopathy } \\
\hline & & & \multicolumn{2}{|c|}{ Group $1(n=8)$} & \multicolumn{2}{|c|}{ Group $2(n=18)$} & \multicolumn{2}{|c|}{ Group $3(n=31)$} \\
\hline & Mean $(S D)$ & Range & Mean (SD) & Range & $\operatorname{Mean}(S D)$ & Range & $\operatorname{Mean}(S D)$ & Range \\
\hline $\begin{array}{l}\text { Ejection fraction (\%) } \\
\text { Peak ejection rate (end } \\
\text { diastolic volume/s) }\end{array}$ & $\begin{array}{l}63(6) \\
3.14(0.53)\end{array}$ & $\begin{array}{l}53-75 \\
2 \cdot 64-4.09\end{array}$ & $\begin{array}{l}69(13) \\
3 \cdot 80(0.88)\end{array}$ & $\begin{array}{l}50-83 \\
3 \cdot 26-5 \cdot 14\end{array}$ & $\begin{array}{l}73(10) \\
3 \cdot 81(1 \cdot 1)\end{array}$ & $\begin{array}{l}62-94 \\
2 \cdot 72-6.80\end{array}$ & $\begin{array}{l}74(12) \\
3.80(1 \cdot 13)\end{array}$ & $\begin{array}{l}47-99 \\
2 \cdot 21-6 \cdot 24\end{array}$ \\
\hline $\begin{array}{l}\text { Time to peak ejection rate (ms) } \\
\text { Systolic ejection period (ms) } \\
\text { RR interval (ms) } \\
\text { Systolic blood pressure } \\
\text { (mm Hg) }\end{array}$ & $\begin{array}{l}136(18) \\
298(42) \\
854(122) \\
125(9)\end{array}$ & $\begin{array}{l}90-184 \\
156-369 \\
700-1071 \\
106-144\end{array}$ & $\begin{array}{l}116(20) \\
317(69) \\
959(169) \\
128(11)\end{array}$ & $\begin{array}{l}76-137 \\
250-472 \\
700-1070 \\
103-156\end{array}$ & $\begin{array}{l}114(41) \\
330(80) \\
944(205) \\
130(11)\end{array}$ & $\begin{array}{l}47-183 \\
240-446 \\
700-1200 \\
100-149\end{array}$ & $\begin{array}{l}113(45) \\
301(56) \\
934(169) \\
136(8)\end{array}$ & $\begin{array}{l}40-224 \\
165-444 \\
731-1250 \\
110-160\end{array}$ \\
\hline $\begin{array}{l}\text { Diastolic blood pressure } \\
\text { (mm Hg) }\end{array}$ & $75(7)$ & $68-90$ & $70(7)$ & $56-86$ & $70(8)$ & $54-88$ & $68(6)$ & $55-84$ \\
\hline
\end{tabular}
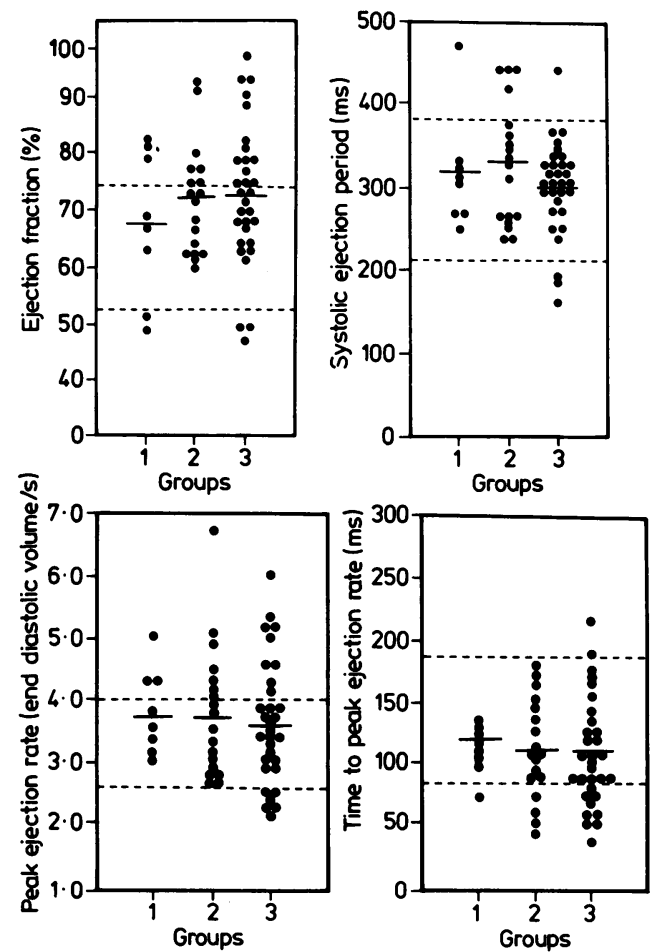

Fig. 3 Ejection fraction, systolic ejection period, normalised peak ejection rate, and time to peak ejection rate are compared in patients with a resting gradient (group 1), with a gradient on provocation (group 2), or without a gradient (group 3). Solid lines indicate mean values. Dashed lines indicate upper and lower limits of normal ( $95 \%$ confidence intervals).

190); group 2, 130 (24) (83-185); group 3, 137 (29) (92-174)).

The interobserver variability of measurements of the proportion of stroke volume ejected in early and late systole was small (Table 3). The proportion of stroke volume ejected during the first third (Fig. 4), first half, and first $80 \%$ (Fig. 5) of systole was

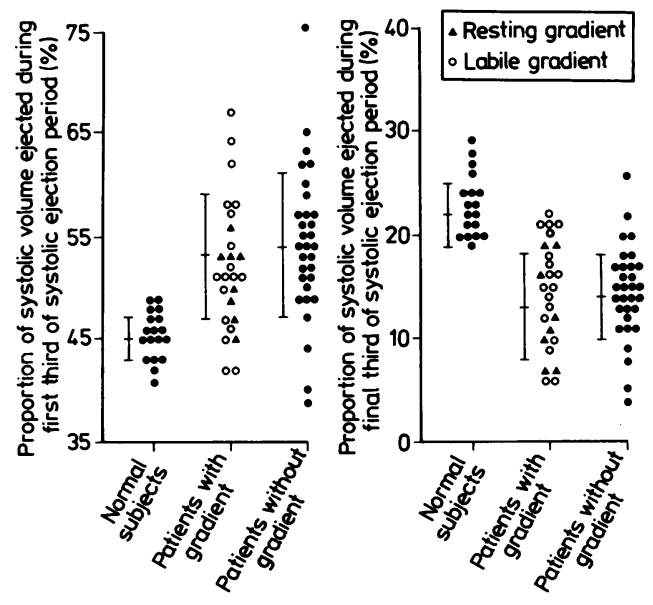

Fig. 4 Relative volumes ejected during first and final third of systolic ejection period in patients and normal subjects.

significantly higher in patients than in the controls (Table 4). There were, however, no significant differences for any of these measurements in the three subgroups with hypertrophic cardiomyopathy.

\section{Discussion}

The present study showed that patients with hypertrophic cardiomyopathy ejected a greater proportion of stroke volume earlier in systole and had a faster peak rate of ejection than did normal subjects. These findings of rapid and early ejection were similarly present in patients with and without left ventricular gradients. The non-invasive method of assessing relative stroke volume confirmed in a large number of patients with hypertrophic cardiomyopathy the work of Murgo et al. ${ }^{30}$ Using a multisensor aortic velocity flow probe, they found that the duration of forward flow, expressed as a percentage of total systolic ejection period, was similar in patients with resting, provoc- 
Table 3 Interobserver variability of radionuclide measurements of proportion of stroke volume ejected during early and late systole in 20 patients with hypertrophic cardiomyopathy

\begin{tabular}{|c|c|c|c|c|}
\hline & \multicolumn{2}{|c|}{ Absolute difference } & \multicolumn{2}{|c|}{ Percentage difference } \\
\hline & $\operatorname{Mean}(S D)$ & Range & $\operatorname{Mean}(S D)$ & Range \\
\hline $\begin{array}{l}\text { Relative (\%) volume ejecte } \\
\text { First third of systole } \\
\text { Middle third of systole } \\
\text { Final third of systole } \\
\text { First half of systole } \\
\text { First } 80 \% \text { of systole }\end{array}$ & $\begin{array}{l}3(2) \\
4(2) \\
2(1) \\
4(3) \\
7(4)\end{array}$ & $\begin{array}{l}0-8 \\
0-9 \\
0-4 \\
0-11 \\
0-16\end{array}$ & $\begin{array}{r}6(4) \\
12(6) \\
9(4) \\
6(5) \\
8(5)\end{array}$ & $\begin{array}{l}0-17 \\
0-28 \\
0-18 \\
0-8 \\
0-6\end{array}$ \\
\hline
\end{tabular}

Table 4 Proportion of left ventricular stroke volume ejected during early and late systole in normal subjects and in patients with hypertrophic cardiomyopathy with a gradient at rest (group 1), a gradient on provocation (group 2), or no gradient (group 3)

\begin{tabular}{|c|c|c|c|c|c|c|c|c|}
\hline & \multirow{2}{*}{\multicolumn{2}{|c|}{$\frac{\text { Normal subjects }}{(n=18)}$}} & \multicolumn{6}{|c|}{ Patients with hypertrophic cardiomyopathy } \\
\hline & & & \multicolumn{2}{|c|}{ Group $1(n=8)$} & \multicolumn{2}{|c|}{ Group $2(n=18)$} & \multicolumn{2}{|c|}{ Group $3(n=31)$} \\
\hline & Mean $(S D)$ & Range & Mean $(S D)$ & Range & Mean $(S D)$ & Range & Mean $(S D)$ & Range \\
\hline $\begin{array}{l}\text { Portion of systole } \\
\text { First third } \\
\text { Middle third } \\
\text { Last third } \\
\text { First half } \\
\text { First } 80 \%\end{array}$ & $\begin{array}{l}45(2) \\
32(3) \\
22(3) \\
65(3) \\
88(1)\end{array}$ & $\begin{array}{l}41-49 \\
28-35 \\
19-29 \\
59-76 \\
85-89\end{array}$ & $\begin{array}{l}51(4)^{\star} \\
35(4) \\
13(5)^{\star \star \star} \\
71(8)^{\star \star} \\
92(5)^{\star \star}\end{array}$ & $\begin{array}{r}45-56 \\
29-40 \\
7-19 \\
59-74 \\
85-98\end{array}$ & $\begin{array}{l}53(7)^{\star \star \star} \\
31(4) \\
15(5)^{\star \star \star} \\
73(11)^{\star \star} \\
91(3)^{\star \star \star}\end{array}$ & $\begin{array}{r}42-67 \\
23-40 \\
6-22 \\
55-81 \\
87-97\end{array}$ & $\begin{array}{l}54(7)^{\star \star \star} \\
31(5) \\
14(4)^{\star \star \star} \\
71(8)^{\star} \\
91(4)^{\star \star \star}\end{array}$ & $\begin{array}{c}39-75 \\
18-39 \\
5-26 \\
61-95 \\
84-100\end{array}$ \\
\hline
\end{tabular}

${ }^{\star} \mathrm{p}<0.01 ;{ }^{\star \star} \mathrm{p}<0.05 ;{ }^{\star \star \star} \mathrm{p}<0.001$, in comparison with normal subjects.

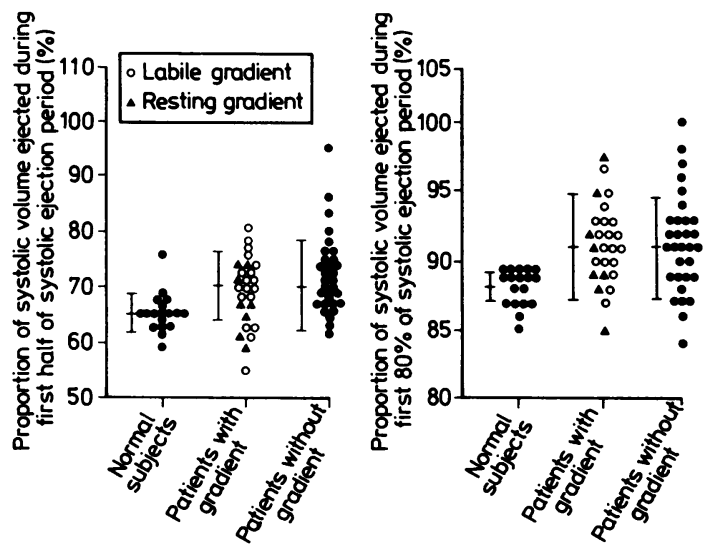

Fig. 5 Relative volumes ejected during first half and first $80 \%$ of systolic ejection period in patients and normal subjects.

able, and no gradient $(69(17) \%, 63(14) \%$, and 61 (16)\% respectively) but was significantly shorter than in normal subjects $(90(3) \%)$. Our findings were also consistent with the results of two earlier invasive studies of aortic flow in a combined total of six patients, all of whom had a left ventricular gradient and in whom $80 \%$ of the stroke volume was ejected by mid systole. ${ }^{31} 32$

Additional information on the relation of abnormalities of left ventricular ejection and gradients has been obtained from measurements of the peak rate of change of left ventricular pressure ${ }^{930}$ and left ven- tricular ejection time. ${ }^{93-41}$ In two studies (85 patients) a higher rate of pressure change was found in the aorta ${ }^{30}$ and brachial artery9 of patients than those of normal subjects; these abnormalities were not associated with left ventricular gradients. Many studies show a prolongation of left ventricular ejection time in patients with hypertrophic cardiomyopathy ${ }^{33-41}$; in three of four studies, however, in which the relation between left ventricular ejection time and the magnitude of outflow gradients was assessed, a poor correlation was found.93841 Although there appeared to be a relation in the study by Wigle et al, ${ }^{37}$ a correlation coefficient was not presented. We have retrospectively reanalysed the data that were presented; there was a weak positive correlation $(r=0.51)$ between left ventricular ejection time corrected for heart rate and the magnitude of the left ventricular gradient. Studies with transcutaneous Doppler $^{42-44}$ or electromagnetic ${ }^{45}$ velocity flow probes placed on the carotid artery, ${ }^{42}$ aorta, ${ }^{43}$ or brachial artery 445 have shown rapid early systolic flow followed by an abrupt decrease in mid systole with a reduced late systolic flow wave. Only qualitative data on flow patterns have been provided by these techniques, the number of patients observed has been small, and a distinction between antegrade and retrograde flow could not always be made. Furthermore, flow patterns were not compared in an appreciable number of patients with and without left ventricular gradients. 
Indices of systolic function are critically dependent on conditions of preload and afterload. ${ }^{46}$ In our study heart rate and systolic and diastolic blood pressure were similar in patients with and without left ventricular gradients and in the normal subjects. Differences in end diastolic volume could explain the observed differences in the proportion of stroke volume ejected during early and late systole between patients and normal subjects. End diastolic volume, however, was similar in all patients with resting, labile, and no gradients and was within a previously determined normal range for angiographic measurements of end diastolic volume. ${ }^{4748}$

The radionuclide technique has several advantages over conventional approaches for assessing systolic function. The technique is free from geometric assumptions, a major advantage in a disease in which left ventricular geometry may be extremely complex. The radionuclide indices are based on averaged values from several hundred complexes (in contrast, left ventricular gradients are conventionally measured from a small number of complexes), and the technique avoids haemodynamic alterations associated with the use of contrast and the technical difficulties of measurement of flow or velocity. In addition, an excellent correlation between the relative changes in volume during the systolic ejection period measured has been found by others from high temporal resolution radionuclide activity time curves and by an electromagnetic flowmeter in the baboon. ${ }^{49}$

In the present study consideration was not given to either the mechanisms whereby left ventricular gradients are generated or whether such gradients represent true obstruction. These questions have been evaluated by others. ${ }^{43-45} 50-60$ Our observation that the relative volumes ejected during early and late systole did not differ between patients with and without a left ventricular gradient raises the question, are such gradients clinically relevant? In the present study there were no differences in the incidence of clinical or prognostic features in patients with and without a left ventricular gradient. Other studies have also noted a similar clinical profile in patients with and without a gradient. Braunwald et al found no correlation between the magnitude of left ventricular gradient and the presence of dyspnoea, angina, syncope, dizziness, or peripheral oedema in 64 patients. 9 Similarly Henry et al found that 24 patients with gradients could not be distinguished symptomatically from 13 without gradients, ${ }^{14}$ and Swan et al made a similar observation in 64 of 85 patients in whom gradients were measured. ${ }^{19}$ Two independent studies that assessed the prevalence of arrhythmias during ambulatory electrocardiographic monitoring in a total of 186 patients found that neither serious ventricular arrhythmia nor episodes of supraventricular tachycardia was associated with left ventricular gradients. ${ }^{15} 16$ Electrocardiographic evidence of left ventricular hypertrophy was equally common in patients with and without gradients. ${ }^{61-63}$ Furthermore, progression of electrocardiographic indices of hypertrophy was not influenced by the presence of a left ventricular gradient. ${ }^{63}$ Finally, the relation between gradient and sudden death has been evaluated in five studies and a total of 532 patients, of whom 93 died suddenly. ${ }^{17-21} \mathrm{~A}$ relation between gradient and sudden death could not be shown in any of the five series.

Combined myotomy and myectomy clearly improves symptoms in most patients. ${ }^{64}$ The fact that operation also decreases systolic gradients does not necessarily indicate that this is the mechanism of symptomatic improvement. Abnormalities of diastolic filling are common, ${ }^{65-73}$ occur independently of abnormalities of ejection, ${ }^{7374}$ are associated with other indicators of poor prognosis, ${ }^{24} 75$ and are predictive of subsequent sudden death in some patients. ${ }^{24}$ The excellent surgical results reported by some centres" 64 may be unrelated to "relief of obstruction," and in this regard the effect of combined myotomy and myectomy on left ventricular diastolic filling requires evaluation.

WJM was supported by a grant from the British Heart Foundation.

\section{References}

1 Braunwald E, Morrow AG, Cornell WP, Aygen MM, Hilbish TF. Idiopathic hypertrophic subaortic stenosis: clinical, hemodynamic, and angiographic manifestations. Am f Med 1960; 29: $924-45$.

2 Brockenbrough EC, Braunwald E, Morrow AG. A hemodynamic technic for the detection of hypertrophic subaortic stenosis. Circulation 1961; 23: 189-94.

3 Braunwald E, Ebert PA. Hemodynamic alterations in idiopathic hypertrophic subaortic stenosis induced by sympathomimetic drugs. Am F Cardiol 1962; 10: 489-95.

4 Braunwald E, Brockenbrough EC, Frye RL. Studies on digitalis. V. Comparison of the effects of ouabain on left ventricular dynamics in valvular aortic stenosis and hypertrophic subaortic stenosis. Circulation 1962; 26: 166-73.

5 Gorlin R, Cohen LS, Elliott WC, Klein MD, Lane FJ. Hemodynamics of muscular subaortic stenosis (obstructive cardiomyopathy). In: Wolstenholme GEW, O'Connor M, eds. Cardiomyopathies: Ciba symposium. London: J and A Churchill, 1964: 76-99.

6 Wigle ED. Cardiovascular drugs in muscular subaortic stenosis. Fed Proc 1965; 24: 1279-86.

7 Shah PM, Yipintsoi T, Amarasingham R, Oakley CM. Effects of respiration on the hemodynamics of hypertrophic obstructive cardiomyopathy. Am $\mathcal{f}$ Cardiol 1965; 15: 793-800.

8 Goodwin JF, Hollman A, Cleland WP, Teare D. Obstructive cardiomyopathy simulating aortic stenosis. $\mathrm{Br}$ Heart $\mathrm{f}$ 1960; 22: 403-14.

9 Braunwald E, Lambrew CT, Rockoff SD, Ross J Jr, Morrow AG. Idiopathic hypertrophic subaortic stenosis. I. A description of the disease based upon an analysis of 64 patients. Circulation 1964; 29 \& 30 (suppl IV): 3-119. 
10 Bulkley BH. Idiopathic hypertrophic subaortic stenosis afflicted: idols of the cave and market place. Am 7 Cardiol 1980; 40: 476-9

11 Goodwin JF. Hypertrophic cardiomyopathy: a disease in search of its own identity. Am f Cardiol 1980; 45: 177-80.

12 Canedo MI, Frank MJ. Therapy of hypertrophic cardiomyopathy: medical or surgical? Clinical and pathologic considerations. Am f Cardiol 1981; 48: 383-8.

13 Murgo JP. Does outflow tract obstruction exist in hypertrophic cardiomyopathy? $N$ Engl f Med 1982; 307: 1008-9.

14 Henry WL, Clark CE, Epstein SE. The clinical characteristics of obstructive and non-obstructive asymmetric septal hypertrophy (IHSS) [Abstract]. Clin Res 1973; 21: 425.

15 Savage DD, Seides SF, Maron BJ, Myers DJ, Epstein SE. Prevalence of arrhythmias during 24 hour electrocardiographic monitoring and exercise testing in patients with obstructive and non-obstructive hypertrophic cardiomyopathy. Circulation 1979; 59: 866-75.

16 McKenna WJ, England D, Doi YL, Deanfield JE, Oakley CM, Goodwin JF. Arrhythmia in hypertrophic cardiomyopathy. I. Influence on prognosis. $\mathrm{Br}$ Heart $\mathcal{F}$ 1981; 46: 168-72.

17 McKenna WJ, Deanfield J, Faruqui A, England D, Oakley CM, Goodwin JR. Prognosis in hypertrophic cardiomyopathy: role of age and clinical, electrocardiographic and hemodynamic features. Am $\mathcal{F}$ Cardiol 1981; 47: 532-8.

18 Frank S, Braunwald E. Idiopathic hypertrophic subaortic stenosis. Clinical analysis of 126 patients with emphasis on the natural history. Circulation 1968; 37: 759-88.

19 Swan DA, Bell B, Oakley CM, Goodwin J. Analysis of symptomatic course and prognosis and treatment of hypertrophic obstructive cardiomyopathy. $\mathrm{Br} \mathrm{Heart} \mathcal{F}$ 1971; 33: 671-85.

20 Maron BJ, Roberts WC, Edwards JE, McAllister HA Jr, Foley DD, Epstein SE. Sudden death in patients with hypertrophic cardiomyopathy: characterization of 26 patients without functional limitation. Am $\mathcal{F}$ Cardiol 1978;41: 803-10.

21 Maron BJ, Lipson LC, Roberts WC, Savage DD, Epstein SE. "Malignant" hypertrophic cardiomyopathy: identification of a subgroup of families with unusually frequent premature death. Am f Cardiol 1978; 41: 1133-40.

22 Shapiro LM, McKenna WJ. Distribution of left ventricular hypertrophy in hypertrophic cardiomyopathy: a two-dimensional echocardiographic study. F Am Coll Cardiol 1983; 2: 437-44.

23 Simon AL, Ross J Jr, Gault JH. Angiographic anatomy of the left ventricle and mitral valve in idiopathic hypertrophic subaortic stenosis. Circulation 1967; 36: 852-67.

24 Newman H, McKenna WJ, Oakley CM, Goodwin JF. The relation of left ventricular function and prognosis in hypertrophic cardiomyopathy: an angiographic study [Abstract]. $\mathcal{f} \mathrm{Am}$ Coll Cardiol 1984; 3: 620.

25 Thrall JH, Freitas JE, Swanson D, et al. Clinical comparison of cardiac blood pool visualization with technetium-99M red blood cells labeled in-vivo and with technetium-99M human serum albumin. F Nucl Med 1978; 19: 796-803.

26 Sugrue DD, McKenna WJ, Dickie S, Oakley CM, Myers MJ, Lavender JP. Equilibrium radionuclide assessment of left ventricular ejection and filling. Comparison of list-mode and multigated frame-mode measurements. Nuclear Medicine Communications 1983; 4: 323-34.

27 Green MV, Bacharach SL, Douglas MA, Borer JS, Johnston GS. Sources of virtual background in multi-image blood pool studies. In: Sorenson JA. Nuclear cardiology: selected computer aspects. New York: Society of Nuclear Medicine, 1978: 97-106.

28 Sugrue DD, Kamal S, Deanfield JE, et al. Assessment of right ventricular function and anatomy using peripheral vein infusion of krypton-81M. Br F Radiol 1983; 56: 657-63.

29 Hoshino T, Tomonaga G, Motomura M, Shimono Y, Kinoshita $M$, Kusukawa $R$. Quantitative analysis of left ventricular ejection phase by means of left ventricular cineangiography. $f_{p n}$ Circ $\mathcal{F}$ 1977; 41: 1085-97.

30 Murgo JP, Alter BR, Dorethy JF, Altobelli SA, McGranahan GM Jr. Dynamics of left ventricular ejection in obstructive and non- obstructive hypertrophic cardiomyopathy. $\mathcal{F}$ Clin Invest 1980; 66: 1369-82.

31 Pierce GE, Morrow AG, Braunwald E. Idiopathic hypertrophic subaortic stenosis. III. Intraoperative studies of the mechanism of obstruction and its hemodynamic consequences. Circulation 1964; 29 \& 30 (suppl 4): 152-213.

32 Hernandez RR, Greenfield JC Jr, McCall BW. Pressure-flow studies in hypertrophic subaortic stenosis. F Clin Invest 1964; 43: 401-7.

33 Boiteau GM, Allenstein BJ. Hypertrophic subaortic stenosis: clinical and hemodynamic studies with special reference to pulse contour measurement. Am f Cardiol 1961; 8: 614-23.

34 Fishleder BI, Bermudez F, Friedland CH. Estenosis subaortica dinamica: su diagnostico clinico y por metodos graficos externos. (Dynamic subaortic stenosis. Its clinical diagnosis and diagnosis by external graphic methods.) Arch Inst Cardiol Mex 1962; 32: $430-51$.

35 Benchimol A, Legler JF, Dimond EG. The carotid tracing and apex cardiogram in subaortic stenosis and idiopathic myocardial hypertrophy. Am $\mathcal{f}$ Cardiol 1963; 11: 427-35.

36 Wilson WS, Criley JM, Ross RS. Dynamics of left ventricular emptying in hypertrophic subaortic stenosis. Am Heart $\mathrm{f}$ 1967; 73: 4-16.

37 Wigle ED, Auger P, Marquis Y. Muscular subaortic stenosis. The direct relation between the intraventricular pressure difference and the left ventricular ejection time. Circulation 1967; 36: 36-44.

38 Harris A, Donmoyer T, Leatham A. Physical signs in differential diagnosis of left ventricular obstructive cardiomyopathy. $\mathrm{Br}$ Heart f 1969; 31: 501-10.

39 Grimberg D, Acar J, Joly F, Humbert G. Intérêt du carotidogramme dans le sténose musculaire idiopathique du ventricule gauche. Etude de 50 cas et de 1,668 cardiopathies diverses. Arch Mal Coeur 1969; 62: 183-92.

40 Carter WH, Whalen RE, Morris JJ Jr, Orgain ES. Carotid pulse tracings in hypertrophic subaortic stenosis. Am Heart f 1971; 82: 180-6.

41 Ibrahim M, Silie M, Delahaye JP, Froment R. Systolic time intervals in valvular aortic stenosis and idiopathic hypertrophic subaortic stenosis. Br Heart f 1973; 35: 276-83.

42 Joyner CR, Harrison FS Jr, Gruber JW. Diagnosis of hypertrophic subaortic stenosis with a Doppler velocity flow detector. Ann Intern Med 1971; 74: 692-6.

43 Boughner DR, Schuld RL, Persaud JA. Hypertrophic obstructive cardiomyopathy. Assessment by echocardiographic and Doppler ultrasound techniques. Br Heart $\mathcal{f}$ 1975; 37: 917-23.

44 Benchimol A, Maia IG, Cartlan JL Jr, Franklin D. Telemetry of arterial flow in man with a Doppler ultrasonic flowmeter. Am $\mathcal{F}$ Cardiol 1968; 22: 75-84.

45 Gault JH, Ross J Jr, Mason DT. Patterns of brachial arterial blood flow in conscious human subjects with and without cardiac dysfunction. Circulation 1966; 34: 833-48.

46 Weissler AM, Peeler RG, Roehll WH. Relationships between left ventricular ejection time, stroke volume, and heart rate in normal individuals and patients with cardiovascular disease. Am Heart $\mathcal{f}$ 1961; 62: 367-78.

47 Gotsman MS, Lewis BS. Left ventricular volumes and compliance in hypertrophic cardiomyopathy. Chest 1974; 66: 498505.

48 Kennedy JW, Baxley WA, Figley MM, Dodge HT, Blackmon JR. Quantitative angiocardiography $I$. The normal left ventricle in man. Circulation 1966; 34: 272-8.

49 Green MV, Ostrow HG, Scott RN, Douglas MA, Bailey JJ, Johnston GS. A comparison of simultaneous measurements of systolic function in the baboon by electromagnetic flowmeter and high frame rate ECG-gated blood pool scintigraphy. Circulation 1979; 60: 312-9.

50 Criley JM, Lewis KB, White RI Jr, Ross RS. Pressure gradients without obstruction. A new concept of "hypertrophic subaortic stenosis." Circulation 1965; 32: 881-7. 
51 Ross J Jr, Braunwald E, Gault JH, Mason DT, Morrow AG. The mechanism of the intraventricular pressure gradient in idiopathic hypertrophic subaortic stenosis. Circulation 1966; 34: 558-78.

52 Wilson WS, Criley JM, Ross RS. Dynamics of left ventricular emptying in hypertrophic subaortic stenosis. A cineangiographic and hemodynamic study. Am Heart $f$ 1967; 73: 4-16.

53 Glancy DL, Shepherd RL, Beiser GD, Epstein SE. The dynamic nature of left ventricular outflow obstruction in idiopathic hypertrophic subaortic stenosis. Ann Intern Med 1971; 75: 589-92.

54 Henry WL, Clark CE, Glancy DL, Epstein SE. Echocardiographic measurement of the left ventricular outflow gradient in idiopathic hypertrophic subaortic stenosis. N Engl f Med 1973; 288: 989-93.

55 Weyman AE, Feigenbaum H, Hurwitz RA, Girod DA, Dillon JC, Chang S. Localization of left ventricular outflow obstruction by cross-sectional echocardiography. Am 7 Med 1976; 60: 33-8.

56 Henry WL, Clark CE, Griffith JM, Epstein SE. Mechanism of left ventricular outflow obstruction in patients with obstructive asymmetric hypertrophy. Am f Cardiol 1975; 35: 337-45.

57 Criley JM, Lennon PH, Abbasi AS, Blaufuss AH. Hypertrophic cardiomyopathy. In: Levine HJ, ed. Clinical cardiovascular physiology. New York, San Francisco, London: Grune and Stratton, 1976: 771-827.

58 Raizner AE, Chahine RA, Ishimori T, Awdeh M. Clinical correlates of left ventricular cavity obliteration. Am f Cardiol 1977; 40: 303-9.

59 Crawford MH, Groves BM, Horwitz LD. Dynamic left ventricular outflow tract obstruction and systolic anterior motion of the mitral valve in the absence of asymmetric septal hypertrophy. Am f Med 1978; 65: 703-8.

60 Maron BJ, Gottdiener JS, Roberts WC, Henry WL, Savage DD, Epstein SE. Left ventricular outflow obstruction due to systolic anterior motion of the anterior mitral leaflet in patients with concentric left ventricular hypertrophy. Circulation 1978; 57: 527-33.

61 Savage DD, Seides SF, Clark CE, et al. Electrocardiographic findings in patients with obstructive and non-obstructive hypertrophic cardiomyopathy. Circulation 1978; 58: 402-8.

62 Joye J, DeMaria AN, Neumann A, Miller RR, Vismara LA, Mason DT. Electrocardiographic abnormalities in hypertrophic cardiomyopathy: relation to cardiac hypertrophy and intraventricular obstruction [Abstract]. Circulation 1976; 54 (suppl II): 209.

63 McKenna WJ, Borggrefe M, England D, Deanfield J, Oakley CM, Goodwin JF. The natural history of left ventricular hypertrophy in hypertrophic cardiomyopathy: an electrocardiographic study. Circulation 1982; 66: 1233-40.
64 McKenna WJ, Goodwin JF. The natural history of hypertrophic cardiomyopathy. Curr Probl Cardiol 1981; 6: 1-26.

65 Stewart S, Mason DT, Braunwald E. Impaired rate of left ventricular filling in idiopathic hypertrophic subaortic stenosis and valvular aortic stenosis. Circulation 1968; 37: 8-14.

66 Moreyra E, Klein JJ, Shimada H, Segal BL. Idiopathic hypertrophic subaortic stenosis diagnosed by reflected ultrasound. Am f Cardiol 1969; 23: 32-7.

67 Sanderson JE, Gibson DG, Brown DJ, Goodwin JF. Left ventricular filling in hypertrophic cardiomyopathy. $\mathrm{Br}$ Heart $\mathrm{f}$ 1977; 39: 661-70.

68 St John Sutton MG, Tajik AJ, Gibson DG, Brown DJ, Seward $\mathrm{JB}$, Giuliani ER. Echocardiographic assessment of left ventricular filling and septal and posterior wall dynamics in idiopathic hypertrophic subaortic stenosis. Circulation 1978; 57: 512-20.

69 Sanderson JE, Traill TA, St John Sutton MG, Brown DJ, Gibson DG, Goodwin JF. Left ventricular relaxation and filling in hypertrophic cardiomyopathy. An echocardiographic study. $\mathrm{Br} \mathrm{Heart} f$ 1978; 40: 596-601.

70 St John Sutton MG, Tajik AJ, Smith HC, Ritman EL. Angina in idiopathic hypertrophic subaortic stenosis. Circulation 1980; 61: 561-8.

71 Lorrell BH, Paulus WJ, Grossman W, Wynne J, Cohn PF, Braunwald E. Improved diastolic function and systolic performance in hypertrophic cardiomyopathy after nifedipine. $N \mathrm{Englf}$ Med 1980; 303: 801-3.

72 Hanrath P, Mathey DG, Siegert R, Bleifeld W. Left ventricular relaxation and filling pattern in different forms of left ventricular hypertrophy: an echocardiographic study. Am $\mathcal{F}$ Cardiol 1980; 45: 15-23.

73 Bonow RO, Rosing DR, Bacharach SL, et al. Effects of verapamil on left ventricular systolic function and diastolic filling in patients with hypertrophic cardiomyopathy. Circulation 1981; 64: 787-96.

74 Hirota Y, Furubayashi K, Kaku K, et al. Hypertrophic non obstructive cardiomyopathy: a precise assessment of hemodynamic characteristics and clinical implications. Am f Cardiol 1982; 50: 990-7.

75 Sugrue DD, Dickie S, Myers M, Lavender JP, McKenna WJ. The relation of left ventricular function to prognostic features in hypertrophic cardiomyopathy [Abstract]. Circulation 1983; 68 (suppl III): 162.

76 Maron BJ, Merrill WH, Freier PA, Kent KM, Epstein SE. Long-term clinical course and symptomatic status of patients after operation for hypertrophic subaortic stenosis. Circulation 1978; 57: 1205-13. 